\title{
Urana subterranean clover (Trifolium subterraneum L. var. subterraneum)
}

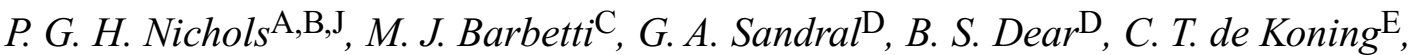

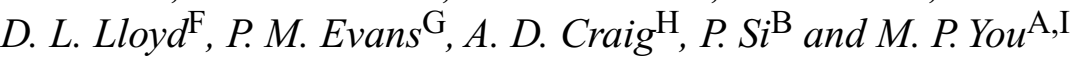 \\ ${ }^{A}$ Department of Agriculture and Food Western Australia, 3 Baron-Hay Court, South Perth, WA 6151, Australia. \\ ${ }^{\mathrm{B}}$ Centre for Legumes in Mediterranean Agriculture, The University of Western Australia, \\ 35 Stirling Highway, Crawley, WA 6009, Australia. \\ ${ }^{\mathrm{C}} \mathrm{School}$ of Plant Biology, The University of Western Australia, \\ 35 Stirling Highway, Crawley, WA 6009, Australia. \\ DNSW Department of Primary Industries, Agricultural Institute, PMB Wagga Wagga, NSW 2650, Australia. \\ ${ }^{E}$ SARDI, Turretfield Research Centre, Rosedale, SA 5350, Australia. \\ F Department of Primary Industries and Fisheries, Queensland, PO Box 102, \\ 203 Tor Street, Toowoomba, Qld 4350, Australia. \\ GDepartment of Primary Industries, Private Bag 105, Hamilton, Vic. 3300, Australia. \\ ${ }^{\text {H}}$ SARDI, Struan Agricultural Centre, PO Box 618, Naracoorte, SA 5271, Australia. \\ ISchool of Earth and Geographical Sciences, The University of Western Australia, \\ 35 Stirling Highway, Crawley, WA 6009, Australia. \\ ${ }^{\mathrm{J}}$ Corresponding author: Email: pnichols@agric.wa.gov.au
}

\begin{abstract}
Urana is a hardseeded, moderately early flowering $\mathrm{F}_{5}$-derived crossbred subterranean clover of var. subterraneum [(Katz. et Morley) Zohary and Heller] developed by the collaborating organisations of the National Annual Pasture Legume Improvement Program. It has been selected for release as a new cultivar on the basis of its high winter and spring herbage production and overall field performance relative to other subterranean clovers of similar maturity. Urana is recommended for sowing in Western Australia, New South Wales, Victoria, South Australia and Queensland. It is best suited to well-drained, moderately acidic soils in areas with a growing season of 5-7 months, which extends into mid-October. Urana is suited to phase farming and crop rotations. It has been granted Plant Breeders Rights in Australia.
\end{abstract}

\section{Origin}

Urana subterranean clover [Trifolium subterraneum var. subterraneum (Katz. et Morley) Zohary and Heller] was bred by P. G. H. Nichols. It is derived from the cross $81 \mathrm{~S} 44$ initiated by J. S. Gladstones in 1981. The pollen parent was the crossbred line 75S13.8.1.1 (Dinninup//Daliak/Toodyay) and the seed parent was the crossbred line 76S11.4.2 (CPI 65313B//Mt Helena A/Daglish).

Cross 81S44 was sown and harvested under the supervision of W. J. Collins as a bulk population at The University of Western Australia Field Station (UFS), Shenton Park, in each of the $\mathrm{F}_{2}, \mathrm{~F}_{3}$ and $\mathrm{F}_{4}$ generations, with no single plant selection. Seed produced from the $\mathrm{F}_{3}$ and $\mathrm{F}_{4}$ generations was screened for hardseededness in a fluctuating $60 / 15^{\circ} \mathrm{C}$ temperature cabinet for 4 months using the procedure of Quinlivan (1961). Hard seed remaining after the 4-month treatment in both generations was sown in the following generation.

In $1986,500 \mathrm{~F}_{5}$ seeds from cross $81 \mathrm{~S} 44$ were sown in a 24-m long row at Wongan Hills Research Station, Western Australia (WA) and randomly thinned to 50 well-spaced plants. Urana, originally known as plant $81 \mathrm{~S} 44-16$, was selected by P. G. H. Nichols as 1 of 9 plants from cross 81S44. Selection was based on early flowering, good vigour and hardseededness. In 1987 and 1988, Urana was grown at UFS as a bulk 1.5-m row. In 1987, 40 seeds were sown, while in 1988, 30 seeds were sown and then thinned down to 10 uniform plants, on the basis of leaf marking, flowering time and growth habit. In 1989 and 1990, $2 \mathrm{~g}$ of Urana seed was grown at UFS in 1-m rows with no further spaced plant selection. In each of the $\mathrm{F}_{6}-\mathrm{F}_{9}$ generations, selection was conducted for low formononetin content [less than $0.2 \%$ of dry matter (DM)], using the procedures of Francis and Millington (1965), early flowering and hardseededness. In each of these generations, the strong winter and early spring vigour of Urana was noted.

In 1991, Urana was selected by P. G. H. Nichols as 1 of 104 early maturing breeding lines of ssp. subterraneum for stage I field evaluation in WA, South Australia (SA), Victoria (Vic.), and Queensland (Qld), while initial evaluation in New South Wales (NSW) commenced in 1993. Field evaluation was conducted as part of the National Annual Pasture Legume Improvement Program (NAPLIP), under the codename of SE003. Urana was one of 16 breeding lines 
selected to enter stage II field evaluation trials in WA, NSW, Vic., SA and Qld. The following collaborators of NAPLIP conducted field evaluation and final selection of Urana: P. G. H. Nichols and P. Si (Department of Agriculture and Food, WA), G. A. Sandral and B. S. Dear (Department of Primary Industries, NSW), C. T. de Koning and A. D. Craig (South Australian Research and Development Institute), D. L. Lloyd (Department of Primary Industries and Fisheries, Qld.) and P. M. Evans (Department of Primary Industries, Vic.). M. J. Barbetti, D. J. Gillespie and M. P. You (Department of Agriculture and Food, WA) conducted screening for disease resistance and D. J. Gillespie conducted further screening for redlegged earth mite resistance. P. G. H. Nichols and P. F. Smith (Centre for Legumes in Mediterranean Agriculture) conducted hard seed screening. The University of WA conducted isoflavone analyses. Further details of trial sites and the field evaluation process are given in Sandral et al. (1998).

Urana was selected for release as a new cultivar in 1998. Selection criteria included high winter and spring herbage production, production and maintenance of seed reserves and regeneration density. Urana is recommended for registration by the collaborating organisations of NAPLIP. It has been granted Plant Breeders Rights in Australia and is described in Nichols (2000). The Department of Agriculture and Food, WA, will maintain breeders' seed.

Urana is named after the town of the same name in southern NSW.

\section{Morphological description}

Urana has a nil leaf mark with no central crescent, arms or bands, under the classification of Nichols et al. (1996). Leaflets, however, produce a brown anthocyanin flush along the midrib under cold and other growth-limiting conditions; anthocyanin flecking is absent. Indentation of distal margins is weak. Calyx tubes have a purplish-red pigmentation along their distal half. Stipules contain weak purplish-red veins when under closed canopies. Stems, petioles, leaflet upper surfaces and peduncles are strongly pubescent.

Growth habit tends to be more erect than other subterranean clovers. Individual plants are very vigorous and produce larger leaves with longer, thicker petioles than varieties of similar maturity. Growth also tends to be more indeterminate. Burr burial is moderately strong. Seeds are black with about 105000 seeds $/ \mathrm{kg}$ when grown under ideal conditions.

\section{Agronomic characters}

Urana is a moderately early flowering variety. In Perth, it flowers about 103 days after sowing in early May, about 1 week later than both Dalkeith and Daliak and about 1 week earlier than both Seaton Park and York. Fresh leaves in spaced plants of Urana contain only a trace $(<0.05 \% \mathrm{DM})$ of formononetin, whereas levels of genistein and biochanin A are about 0.8 and $1.5 \%$ DM, respectively (Nichols 2000). The very low level of formononetin indicates a low potential for Urana to cause sheep infertility problems.

Urana is hardseeded compared with other subterranean clovers. Over 6 seasons Urana seeds derived from 1-m single rows averaged $67 \%$ hard seed after 16 weeks in a $15 / 60^{\circ} \mathrm{C}$ cabinet, using the standard laboratory procedures of Quinlivan (1961), whereas York, Dalkeith, Nungarin, Daliak and Seaton Park had 58, 56, 55, 40 and 25\% hard seed, respectively. Laboratory results from spaced plants (Nichols 2000) and field results (Norman et al. 2006) support these relative differences.

Urana is susceptible to Race 1 and moderately susceptible to Race 2 of clover scorch disease caused by Kabatiella caulivora (Kirchn.) Karak. Urana had a disease severity rating of 7.0 in a Race 1 field screening trial at Mt Barker, WA, compared with scores for Seaton Park, Dalkeith, York, Junee and Daliak of 7.0, 7.5, 5.0, 3.0 and 2.5, respectively (increasing disease severity scale of $0-10$ ). In a Race 2 screening trial at Condingup, WA, Urana had a disease severity rating of 4.1, compared with Daliak with 5.2, Junee with 7.0, Dalkeith with 7.4 and both Seaton Park and York with 8.2 (increasing disease severity scale of $0-10$ ).

Urana is highly susceptible to cercospora leafspot (Cercospora zebrina Pass.). Inoculated field plots of Urana had cercospora leafspot incidence not significantly different to Dalkeith or Daliak, while leaf collapse was more severe than Daliak and similar to Dalkeith (Barbetti and Nichols 2005). Observations of seed increase rows in plastic-covered screen houses indicate that Urana has some susceptibility to powdery mildew (Erysiphe polygonii DC) under ideal disease epidemic conditions. Disease incidence under similar conditions, however, was much lower than in Coolamon and it is unlikely that powdery mildew will cause severe losses in grazed Urana swards. The relative susceptibility of Urana to leaf rust (Uromyces trifolii-repentis Liro) has not been determined, but no epidemics of the disease have been observed on Urana in breeding rows or field trials.

Urana is susceptible to both Race $\underline{001}$ and Race 173 (formerly known as Race 0 and Race 1, respectively, and recently recoded by You et al. 2005c), 2 of the most widespread races of root rot caused by Phytophthora

Table 1. Mean field performance data of Urana (as a percentage of Dalkeith) in 21 field trials across southern Australia

Not all traits were measured at each site in every year

\begin{tabular}{lccrc}
\hline $\begin{array}{l}\text { Subterranean } \\
\text { clover type }\end{array}$ & $\begin{array}{c}\text { Herbage } \\
\text { production } \\
\text { Years 1-3 }\end{array}$ & $\begin{array}{c}\text { Seed } \\
\text { bank } \\
\text { Years 1-3 }\end{array}$ & \multicolumn{2}{c}{$\begin{array}{c}\text { Seedling regeneration } \\
\text { density }\end{array}$} \\
\hline Urana & 114 & 82 & 89 & 115 \\
Dalkeith & 100 & 100 & 100 & 100
\end{tabular}

A Three sites only. 
clandestina Taylor, Pascoe and Greenhalgh. Glasshouse trials showed Urana was less susceptible to Race $\underline{0} 01$ than Woogenellup, but more susceptible than Dalkeith, Junee, Seaton Park and York. Urana was not significantly different in Race 173 susceptibility to Woogenellup, Dalkeith or York, but was more susceptible than Seaton Park (You et al. 2005a). Urana is moderately susceptible to root rot caused by Pythium irregulare Buisman. Glasshouse trials showed Urana suffered less tap- and lateral-root damage than Dalkeith and Woogenellup but more damage than York and Seaton Park (You et al. 2005b). Urana is also moderately susceptible to root rot caused by Fusarium avenaceum (Fr.) Sacc. In glasshouse trials, Urana suffered less tap- and lateral-root damage than Seaton Park but damage was not significantly different from York, Dalkeith or Woogenellup (You et al. 2005b).

Urana is similar in susceptibility to redlegged earth mite to other cultivars, Halotydeus destructor (Tucker), particularly at the cotyledon stage. Growth room tests on 2 -week-old seedlings gave mean cotyledon damage ratings of 4.1 for Urana, 5.6 for York, 6.2 for Daliak, 6.4 for Dalkeith and 6.5 for Seaton Park (on an increasing damage severity rating of $0-10)$.

Field performance of Urana was measured in 21 trials at low rainfall sites across southern Australia (Sandral et al. 1998). Its performance is compared with that of Dalkeith, a common treatment at each site, in Table 1. The most outstanding feature of Urana is its high herbage production, which averaged 14\% more over all trials than Dalkeith. This can be attributed to its high seedling vigour and to its relatively indeterminate growth under favourable spring conditions. Mean seed banks were lower in Urana, although this may have been a reflection of dry spring conditions at several sites, which would have advantaged the earlier maturity of Dalkeith. Mean seedling density of Urana was lower than Dalkeith in the second and third years after sowing. This can be attributed to its lower seed banks and to its greater hard-seededness. Limited data from 3 sites suggested stronger seedling regeneration of Urana than Dalkeith in subsequent years.

Urana is recommended for sowing in WA, NSW, Vic., SA and Qld. It is best suited to well-drained, moderately acidic $\left(\mathrm{pH}_{\mathrm{Ca}} 4.5-6.5\right)$ soils in areas with a growing season of 5-7 months that extends into mid-October. Typically this will encompass areas previously sown to Daliak. Urana is well suited to phase farming systems and its high hardseededness allows it to persist more strongly in crop rotations than other older subterranean clover cultivars. Urana is likely to be used in mixtures with Dalkeith, Seaton Park and York.

Seed licenced to: Lachlan Valley Seeds Pty Ltd, trading as Premier Seeds, PO Box 40, Forbes, NSW 2871, Australia.

\section{Acknowledgments}

The Grains Research and Development Corporation (GRDC) and Australian Wool Innovation (AWI) provided funding for the selection and evaluation of Urana. The excellent technical assistance of John Titterington, Duncan Wood, Peter Skinner, Michael Davies, Jonas Hodgeson, Simon Ambrose, Rosemary Lugg, Bev Roberts, Deborah Ambrose, Craig Rodham, Gabriel Dyce, Brett Wilson, Joshua Taylor, Trevor Rowe, Neil Schubert, Neil Cameron, Alan Byron, Brian Johnson; Kemp Teasdale, and Sue O'Brien in the development of Urana is greatly appreciated. We also wish to thank farmers and Research Station staff for their co-operation.

\section{References}

Barbetti MJ, Nichols PGH (2005) New sources of resistance to Cercospora zebrina in subterranean clover. Australasian Plant Pathology 34, 197-201. doi:10.1071/AP05017

Francis CM, Millington AJ (1965) Varietal variation in the isoflavone content of subterranean clover: its estimation by a microtechnique. Australian Journal of Agricultural Research 16, 557-564. doi:10.1071/AR9650557

Nichols PGH (2000) Trifolium subterraneum var. subterraneum subterranean clover 'Urana'. Plant Varieties Journal 13, 89-91.

Nichols PGH, Collins WJ, Barbetti MJ (1996) Registered cultivars of subterranean clover - their characteristics, origin and identification. Agriculture Western Australia Bulletin No. 4327.

Norman HC, Smith FP, Nichols PGH, Si P, Galway NW (2006) Variation in seed softening patterns and impact of seed production environment on hardseededness in early maturing genotypes of subterranean clover. Australian Journal of Agricultural Research 57, 65-74. doi:10.1071/AR05116

Quinlivan BJ (1961) The effect of constant and fluctuating temperatures on the permeability of the hard seeds of some legume species. Australian Journal of Agricultural Research 12, 1009-1022. doi:10.1071/AR9611009

Sandral GA, Dear BS, Nichols PGH, de Koning CT, Evans PM, Lloyd DL (1998) A comparative performance of early flowering subterranean clover genotypes. In 'Proceedings of the 9th Australian Agronomy Conference'. (Eds DL Michalk, JE Pratley) pp.181-184. (The Australian Agronomy Society Inc.: Melbourne)

You MP, Barbetti MJ, Nichols PGH (2005a) New sources of resistance in Trifolium subterraneum L. to root rot caused by two races of Phytophthora clandestina Taylor, Pascoe and Greenhalgh. Australian Journal of Agricultural Research 56, 271-277. doi:10.1071/AR04293

You MP, Barbetti MJ, Nichols PGH (2005b) New sources of resistance identified in Trifolium subterraneum breeding lines and cultivars to root rot caused by Fusarium avenaceum and Pythium irregulare and their relationship to seedling survival. Australasian Plant Pathology 34, 237-244. doi:10.1071/AP04092

You MP, Barbetti MJ, Sivasithamparam K (2005c) Characterization of Phytophthora clandestina races on Trifolium subterraneum in Western Australia. European Journal of Plant Pathology 113, 267-274.

Received 16 March 2005, accepted 27 October 2005 